\title{
Evaluating the Efficiency of Forestry Policy for Inclusive Growth in Ghana
}

\author{
Jonathan D. Quartey \\ Department of Economics, Kwame Nkrumah University of Science and Technology, \\ Kumasi, Ghana. \\ Email:jdquartey@yahoo.com \\ and \\ Anthony K. Osei-Fosu \\ Department of Economics, Kwame Nkrumah University of Science and Technology, \\ Kumasi, Ghana. \\ Email: oseifosuanthonykofi@yahoo.com \\ DOI//http://dx.doi.org/10.4314/gjds.v15i2.6
}

\begin{abstract}
The study evaluates the efficiency of forestry policy implemented in Ghana, where about $70 \%$ of the population depends on forest resources for livelihood and cultural purposes. It sought to assess how efficiently forestry policy had been implemented in Ghana, to inform policy on how benefits of forestry policy could promote inclusive growth. It employs an inclusive wealth framework to ascertain the social opportunity cost due to forestry policy implementation in Ghana, an indicator of the economic welfare effect of the policy. The results show negative net divergence in revenue due to forestry policy implementation, indicating a distorting influence of forestry policy on Ghana's forestry sector, creating increasing inefficiency. Computed summary ratios - Nominal Protection Coefficient, Effective Protection Coefficient and Subsidy Ratio to Producers, confirmed that forestry policy implementation in Ghana had induced lower economic welfare in the country. Ghana will need to apply the holistic model, with special emphasis on the economic and social subsectors to ensure that implemented forestry policy leads to inclusive growth.
\end{abstract}

Keywords: Efficiency, Forestry policy, Ghana, Inclusive growth, Policy analysis matrix

\section{Introduction}

Natural capital has been widely recognised as a crucial component of the total wealth of nations (Gundimeda \& Atkinson, 2014). Following this recognition, one 
important step toward inclusive growth through natural capital which remains largely underutilised, is the role of natural capital policy in inclusive growth. Evidence on this role necessarily involves evaluation of natural capital policy as a tool for inclusive growth. This implies an examination of changes in human wellbeing as a result of policy induced changes in natural capital. One of such natural capital resources which has attracted extensive policy interventions globally are forests.

Forestry policy in Ghana has provided for forest conservation, protection of water bodies, the provision of favourable conditions for cultivation of agricultural crops, and the promotion of public education and research since 1948 (Ghana Forestry Commission, 1994). In spite of these policies and interventions, the destruction of the country's natural forests continues at an alarming rate of about $2 \%$ per annum (Boon et al., 2009; Ghana Forestry Commission, 2012).

Baah-Nuakoh (2003) warned about the possibility of Ghana losing all its forest cover within 30 years, if the rate of deforestation which was 65,000 hectares per annum in 2003 and about 135,395 hectares per annum in 2010 (FAO, 2010), was not checked. Forestry policy could have a major role to play in reversing the current trend. The fundamental issue however is, if formal forestry policy has existed in Ghana since 1908 and yet the current trend has been the order of events, then, there is a need for research to ascertain the role forestry policy has played and continues to play towards successful forestry and hence human welfare improvement in Ghana. Would the situation have been worse if there were no formal forestry policy?

Forest resources are essentially scarce goods with positive accounting prices. If they depreciate through policy implementation, there is social loss, rendering the resulting growth non-inclusive.

Sustainable inclusive growth for any economy essentially requires additions to inclusive wealth stock, which are additions to the set of capital assets as a means of sustaining current and future well-being. Such additions could be obtained through forestry policy only when its implementation is efficient.Inclusive wealth refers to changes in the overall value of all assets in a country over time. This must be positive if the economy is to be considered on a sustainable trajectory (Gundimeda \& Atkinson, 2014). This implies that for inclusive growth to occur, forestry policy must be efficiently implemented. Inefficiency means wastage, leading to depreciation of the resource, which will lead to welfare loss and hence a drag on inclusive growth. 
Thus, sustainable inclusive growth would require efficient and equitable natural resource allocation particularly in developing countries, where, a substantial proportion of people depend mainly on natural resources for survival. Inefficient policies will lead to misallocation of resources and therefore inefficient practices which will result in wastage, economically unsustainable forestry practices and dedevelopment.

This study was motivated by the prospect that forest endowments can contribute positively to inclusive growth in developing countries. This is against the background of a general failure of forestry policy to secure economic development in forest rich developing countries, contrary to the situation in most forest rich developed countries (Alemagi, Samjee \& Davis, 2007).

The purpose of the study was to evaluate the efficiency of forestry policy implementation in Ghana. Efficient implementation of forestry policy is an indicator of sustainable inclusive growth. This makes efficient policy on forest resources a necessity, since inefficiency in forest resource use will trade-off a disproportionate amount of human welfare. This paper thus contributes to existing literature and applied policy evaluation procedure for forestry policy as a driver of economic development in a forest-rich developing country context. Insights from the study provide useful lessons for developing countries in their quest to achieve inclusive growth through forest resources.

\section{The Problem}

The FAO (2015) found that the world lost six per cent of its natural forests between 1990 and 2015. This loss was double the previous rate, while tropical forests have took the hardest hit with a loss rate of ten per cent within the same period (FAO, 2015). This is against the background that the world needs to increase forest area across all domains to provide for the forest benefits and services of a growing population through continued policy focus (Keenan, 2015). Forest is being more rapidly lost in some of the poorest countries, including Ghana despite several policy interventions (FAO, 2015).

The citing of Ghana by FAO (2015) as losing forests rapidly despite several policy interventions raises a question on how efficient these policies have been. This is against the background that Ghana, being a developing country with about 70 per cent of its citizens dependent on forest resources for livelihood and cultural purposes (Ghana Forestry Commission, 2012), would necessarily have to efficiently apply forestry policy to attain inclusive growth and development. Forestry policies have been implemented in Ghana over the past one hundred years with varying 
degrees of outcomes. These outcomes to a large extent depended on how efficiently the policies were implemented. Even though economic resources have been consistently devoted to forestry policy formulation and implementation in Ghana since the early twentieth century, the economy has consistently lost between 4-10 per cent of GDP per annum through deforestation and degradation of forests, particularly in recent times (World Bank, 2006; Ghana Forestry Commission, 2012). This trend of events, while giving some indication of possible inefficiency also appears to be a setback to inclusive growth and development.

In addition, the extent of forestry policy's contribution to inclusive growth and development in Ghana needs to be ascertained, being an important sector of government spending. The seeming abundance of forest resources appears to have given a false sense of resilience to forest abuse, wastage and misuse which could affect inclusive growth and development. However, the literature on forestry in Ghana is completely silent on details of the nexus between forestry policy and inclusive growth. The state of affairs thus demands answers to questions regarding how efficiently forestry policy has been implemented to drive inclusive growth in Ghana.

This paper therefore evaluates how efficiently forestry policy has been implemented in Ghana. It undertakes a Policy Analysis Matrix (PAM) assessment of the economic efficiency of the implementation of forestry policy in Ghana through profitability, divergence and ratio analyses. The following section presents the theoretical framework for the study, followed by the analytical framework. The analysis and discussion of the results then follow. The paper finally concludes with some policy implications drawn from the major findings of the study.

\section{Forestry Policy in Ghana}

The policies of central government on Ghana's forests started during the late 1880s through the colonial authorities (World Bank, 2006). Kotey, Francois, Owusu, Yeboah, Amanor \& Antwi (1998) argued that the period 1874 to 1939 was the consultative phase of forestry policy in Ghana. This period among other things witnessed the introduction of colonialism, the formal trade in timber, and increase in cocoa production through forestry activities and the formation of a forestry department. Subsequently, from 1908 to 1993 the various phases of Ghana's colonial era forestry policy were formulated and implemented.

Ghana's first formal colonial forestry policy was adopted in 1948. Between 1948 and 1993, several legal instruments seeking to complement the provisions of the 1948 
policy were put in place. However, it is worth noting that not until after 1994, Ghana was essentially still operating the colonial forestry policy.

The 1994 forestry and wildlife policy aimed at conserving and sustaining the development of Ghana's forest resources for maintenance of environmental quality and perpetual flow of optimum benefits to all segments of society (Ghana Forestry Commission, 1994). These objectives show that the ultimate aim of the 1994 forestry and wildlife policy was to enhance the social, economic and ecological welfare of Ghanaians. This ultimate aim of forestry policy in Ghana provides a direct justification for evaluating forestry policy for inclusive growth. Even though the most recent forestry policy in Ghana was formulated in 2012 (Ghana Forestry Commission, 2012), an effective evaluation of Ghana's forestry policy can be performed only up to the end of the period of operation of the 1994 policy, that is 1994 to 2011.

The new policy has just been adopted for use as a result of some waiting period for the formulation of the master plan, adopted in September 2016, which defines the operational framework. The 2012 policy aims at the conservation and sustainable development of forest and wildlife resources for the maintenance of environmental stability and continuous flow of optimum benefits from the socio-cultural and economic goods and services that the forest environment provides to the present and future generations, whilst fulfilling Ghana's commitments under international agreements and conventions (Ghana Forestry Commission, 2012). Essentially, with the exception of additions related to climate, the 2012 policy is not very different from the 1994 policy in its objectives.

Ghana's growth has depended principally on the exploitation of forests, mineral and land resources (ISSER, 2011) resulting in a net loss of natural capital. However, the depletion and degradation of these resources has not been recognised as a setback to economic development. It is worth noting that not much attention has been paid to issues about whether the exploitation of natural resources have been really beneficial to the citizenry economically, socially and environmentally. The Institute of Economic Affairs (IEA, 2011) confirmed that within a period of 100 years, Ghana had depleted over $82 \%$ of its forest resources, leaving only a meagre $18 \%$ for future generations.

\section{Conceptual Framework}

To evaluate wealth based policy, a systems approach needs to be adopted to determine its full influence on movements of all capital stocks. Total wealth can be classified into four main types of capital stock namely; man-made capital, 
human capital and natural capital. Figure 1 illustrates the concept of an economy as a dynamic system of linked capital stocks. The integrated nature of these capital stocks means a policy which affects any one element within the system also affects the others through various links. The figure comprises of linked feedback relationships affecting well-being through economic activity.

Well-being encompasses not only income but also dimensions such as educational opportunity, health and quality of life, natural landscapes and ecosystems, and social networks and relationships, among others. Human capital comprises exclusively education, skills, and tacit knowledge. Natural capital is made up of non-renewable and renewable resources and local and global ecosystems- to provide the goods and services society enjoys. Benefits of man-made capital such as access to reliable electricity, better schools and hospitals, and modern technology and education enhance labor productivity.

The relationships are two-fold; reinforcing (positive feedback) and negative feedback relationships, which are shown by positive and negative signs respectively in Figure 1. For instance, increasing economic activity in an economy drives economic growth, which also causes an increase in the stock of man-made capital. This generates further activity within the economy, creating a reinforcing relationship toward economic growth and eventually well-being. The channel for the operation of a second reinforcing relationship is human capital. Generally, a growing stock of human capital leads to a growing stock of man-made capital, causing production and consumption to increase (Collins et al., 2014; Romer, 1989). The negative feedback relationships operate through the depletion of natural resources, showing as negative influences through economic activity in Figure 1. A growing stock of man-made capital results in a decline in natural capital stock, eventually diminishing the natural resource dependent man-made capital (Collins et al., 2014). The effect of depletion of stocks of natural capital on human capital caused by pollutants and degradation of the ecosystem is also captured by the negative feedback relationships.The process generates some amount of pollution, which may negatively affect the surrounding communities. Well-being may decline directly as a result of simply seeing or coming into contact with the pollution, but to illustrate the links between capital stocks the study focused also on the impacts that pollution has on human, natural and man-made capital. 


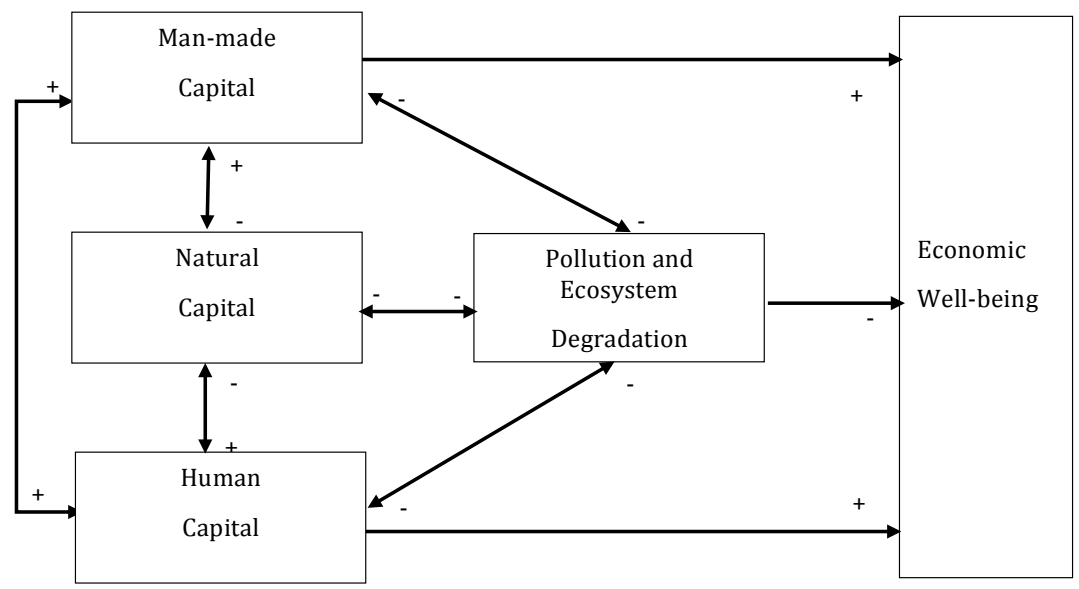

\section{Figure 1: Unidirectional link between capital stock dynamics and economic well-being}

Source: Authors' construct (December, 2016).

The outcome therefore confirms the central tenet of inclusive wealth theory, which states that well-being moves in the same direction as wealth, the value aggregation of all capital stocks in an economy's productive base (Dasgupta, 2009; Arrow et al., 2003).

Hence the implications of well-being as a dynamic system of capital stocks are the following:

If, $f(R) \geq g(B)$ where $f$ and $g$ are functions of the reinforcing relationships and negative feedback relationships respectively, then, inclusive growth and development would be sustainable.

\section{Theoretical Framework}

\section{Theory of Natural Capital Policy}

The Theory of Inclusive Wealth proposes the sustenance of the productive base of society's set of capital assets as a means of sustaining intergenerational wellbeing (Dasgupta \& Maler, 200o). This means for any policy to contribute positively to inclusive wealth of a society, the present discounted value of its social profits will have to be positive and therefore acceptable (Arrow, Dasgupta \& Maler, 2003). Inclusive wealth analysis offers criteria for evaluating natural capital policy by means of changing capital stocks which generally constitute the basic drivers of development (Collins, Sakhrani, Selin, Alsaati \& Strzepek, 2014). 


\section{Theory of Natural Capital Policy Evaluation}

The simplest way to describe a region's inclusive wealth is by accounting for its consumption-saving decisions (Dasgupta, 2009). We assume the region has a constant population size and operates a deterministic, competitive market economy. Thus if $C(t)$ is the region's consumption rate, then the region's wealth changes according to the equation,

$(d W(t)) / d t=r W(t)-C(t)$

(1)

Where represent $t(\geq 0)$ time, $r(>0)$ the market interest rate and $W(t)$ wealth at $t$. From equation 1 , for the region's wealth never to decrease, its consumption $(C(t))$ must never exceed its income $(r W(t))$. The Hicksian definition of "income" as the maximum consumption rate that maintains wealth generalises this idea.

\section{The Measure of Well-being}

To attain inclusive growth, concrete facts concerning recent performance of an economy and how it is likely to perform under alternative policies need to be understood and engineered. This requires evaluation of the economy concerned at a point in time, particularly before and after a perturbation has occurred. Such an evaluation would require criteria whose choice must be justifiable on ethical grounds (Dasgupta, 2008).

If a policy starts from $t=0$ and ends at $t=T$, the policy can have an effect on an existing allocation mechanism such an effect could be indefinite irrespective of the implementation period of the policy. Assuming the output of the policy at $t \epsilon[0, T]$ is $\Delta Y(t)$ which was derived from using up $\Delta K(t)$ and $\Delta L(t)$ units, respectively, of manmade capital and human capital through extracting more natural capital at the rate $\Delta R(t)$. To evaluate this project, we proceed as below, noting that for an efficiently formulated policy equation (2) would be true:

$\Delta Y(t)=(A \partial F / \partial K) \Delta K(t)+(A \partial F / \partial L) \Delta L(t)+(A \partial F / \partial R) \Delta R(t)$

Assuming the project was not designed efficiently, then, the policy's implementation would alter $\Delta C(t)$. The corresponding alteration to $U(t)$, the instantaneous well-being at time $t$, would be $U^{\prime}(C(t)) \Delta C(t)$. This alteration would be made up of both direct and indirect changes which would go beyond the period $\mathrm{T}$. Shadow prices provide a way of estimating $\Delta C(t)$ through a valuation of the output of the policy, the excess natural capital extracted as well as the reallocations of man-made and human capital resources (Dasgupta, 2009). 
To derive the measure of well-being due to natural capital policy, the study assumed the following in line with Dasgupta (2009):

$\mathrm{U}^{\wedge^{\prime}}(\mathrm{C}(\mathrm{t}))=$ shadow price of $;$

$\delta(>0)=$ the rate of time discount

$\xi(\mathrm{t})=$ shadow rental on man-made capital;

$\theta(t)=$ shadow wage rate

$\mathrm{n}(\mathrm{t})=$ shadow price of $\Delta \mathrm{R}(\mathrm{t})$;

$\mathrm{y}(\mathrm{t})=$ shadow price of $\mathrm{Y}(\mathrm{t})$

From the above definitions, the contribution of the policy to well-being is given as:

$$
\int_{0}^{\infty}\left[U^{\prime}(C(t)) \Delta C(t) e^{-\delta t}\right] d t
$$

It is therefore concluded that

$$
\begin{gathered}
\int_{0}^{\infty}\left[U^{\prime}(C(t)) \Delta C(t) e^{-\delta t}\right] d t \\
=\int_{0}^{T}\left[(y(t) \Delta Y(t)-\theta(t) \Delta L(t)-\xi(t) \Delta K(t)-n(t) \Delta R(t)) e^{-\delta t}\right] d t
\end{gathered}
$$

The right hand side of Equation 3 represents the present discounted value of social profit of the policy. The left hand side of Equation 3 equals $\Delta V(\mathrm{o})$, the latter being the change in well-being at $\mathrm{t}=\mathrm{o}$ that would be brought by the policy. So, Equation 3 can be re-expressed as

$$
\Delta V(0)=\int_{0}^{T}\left[(y(t) \Delta Y(t)-\theta(t) \Delta L(t)-\xi(t) \Delta K(t)-n(t) \Delta R(t)) e^{-\delta t}\right] d t
$$

Equation 4 provides the criterion for policy evaluation:

Criterion: A policy should be accepted if and only if the present discounted value of its social profit is positive.

This means the policy brings positive change in well-being to society. Since inclusive wealth at $t$ is the shadow value of the economy's complete list of capital assets, the policy re-allocates these capital assets. The present discounted value of social profits occurring on the right hand side of Equation 4 represents the change the policy would make to inclusive wealth at $\mathrm{t}=\mathrm{o}$ by the marginal reallocation of capital assets in the economy. This is also called the efficiency criterion for natural capital policy evaluation. 


\section{Method of Study}

\section{Research Design}

The design of this study is quantitative and non-experimental. It employs secondary data to assess the efficiency of forestry policy, forests being one set of the stock of natural capital. The usefulness of integrated models for wealthbased policy analysis guided the choice of model for the study. This is because the study required a method of implementing the systems view of holistic welfare in evaluation by capturing capital stock linkages and interactions. Models which focused exclusively on either the physical world or the economy cannot readily do this (Collins et al., 2014). The study consequently evaluated Ghana's forestry policies as one cumulative system to determine whether or not inclusive wealth (and therefore well-being) increased or decreased as a result of the forestry interventions so far implemented.

Secondary data for the study was obtained from the Forestry Commission of Ghana (FC) data compiled by Hamilton Resources and Consulting in collaboration with the Danish Centre for Forest, Landscape and Planning, Denmark (Birikorang, Hansen \& Treue, 2007) and the Institute of Social, Statistical and Economic Research of the University of Ghana (ISSER, 2007), covering the period 2000 to 2007.

\section{Analytical Framework}

The analytical technique used for assessing the efficiency of forestry policy implementation in Ghana is the Policy Analysis Matrix (PAM). The PAM is a computational framework, developed by Monke \& Pearson (1989) and augmented by Masters and Winter-Nelson (1995), for measuring input use efficiency in production, and the degree of government interventions (Nelson \& Panggabean, 1991). The PAM is formatted as a matrix with two-way resource accounting identities.

Theoretically, it measures the efficiency evaluation criterion derived earlier. This technique was selected because of its unique capacity to assess the efficiency of implemented natural resource policy. Its application in literature has been mainly for agricultural policy purposes (Seini, 2002), but is also recommended for natural forest evaluations (Monke \& Pearson, 1989).

\section{Identities of the Policy Analysis Matrix}

The PAM for a forestry system facilitates the computation of the competitiveness of the system in the form of private profitability, obtained through the top row of the 
matrix (Table 1). Social profitability which estimates the social opportunity costs of inputs are computed from the second (middle) row, while the transfer effect of policy implementation are computed from the third row of the matrix.

Table 1: Entries in the policy analysis matrix

\begin{tabular}{|l|l|l|l|}
\hline & Revenues & Costs & Profits \\
\hline Private prices & $\mathrm{R}_{\mathrm{p}}$ & $\mathrm{C}_{\mathrm{p}}$ & $\mathrm{P}_{\mathrm{p}}$ \\
\hline Social prices & $\mathrm{R}_{\mathrm{s}}$ & $\mathrm{C}_{\mathrm{s}}$ & $\mathrm{P}_{\mathrm{s}}$ \\
\hline $\begin{array}{l}\text { Effects of } \\
\text { Divergences }\end{array}$ & $\mathrm{D}_{\mathrm{r}}$ & $\mathrm{D}_{c}$ & $\mathrm{D}_{\mathrm{p}}$ \\
\hline
\end{tabular}

Source: Based on Monke \& Pearson (1989)

Note: Private profit: $P p=R p$-Cp; Social profit: $P s=R s-C s$; Output transfer: $D r=R p$-Rs; Input transfer: $D c=C p-C s ;$ Net policy transfer: $D p=P p-P s$.

Research Inputs and Outputs in the Policy Analysis Matrix

Four groups of entries in the PAM constitute the research inputs for empirical analysis. These are $R_{p}, C_{p}, R_{s}$ and $C_{s}$ whose values are obtained from activity budgets, government documents or industry sources of the sector of the economy concerned. Due to the fact that the PAM is based on two identities, the entry of the research inputs will lead to the generation of the remaining inputs, referred to as research outputs.

The research results of the PAM approach, also called the revenue outputs are obtained through either the profitability or divergence identity by subtraction among the corresponding entries of the research inputs as discussed earlier. The net transfer, described as either the net effect of all divergences or difference between private and social profitability, is a single measure which shows the extent to which policy implementation has been efficient (Monke \& Pearson, 1989).

\section{Evaluating Efficiency of Forestry Policy}

\section{Entries in the Policy Analysis Matrix}

Entries in the PAM matrix were derived in ways discussed below and shown in Table 2. Revenue in private prices (that is US\$465.8) was revenue per cubic meter of timber for Ghana (ISSER, 2008), to conform to the period of enumeration for Forestry Commission (FC) cost data. The average revenue for the past decade was US $\$ 456.4$, suggesting stable annual revenue for the decade. Similarly, cost estimates of the Forestry Commission with regard to natural forests have been very stable 
over the past decade. The revenue in social prices (prices that would result in the best allocation of resources and thus highest generation of income) (US\$511) was obtained by adding the tax based on Ghana's log export ban (US\$35 $\mathrm{m}^{-3}$ ) and stumpage and export levies (US\$10.2 $\mathrm{m}^{-3}$ ) to private revenue (US\$465.8).

The inputs cost in private prices (US\$15.3) was obtained from the FC data on private costs incurred in natural forest management. Private profit (US\$450.5) was obtained by subtracting private input costs from private revenue. The costs in social prices (US\$20.9) were obtained from the social costs of FC forest management. Profit in social prices (US\$490.1) was found by subtracting social costs (US\$20.9) from social revenue (US\$511).The effects of divergences (third row of PAM matrix) are identically equal to the differences between entries in the first row (measured in private prices) and entries in the second row (measured in social prices). These are with respect to revenue (-US\$45.2), costs (-US\$5.6) and profit (-US\$39.6).Table 2: The policy analysis matrix (PAM) for forestry in Ghana

\begin{tabular}{|l|l|l|l|}
\hline Natural Forest (Production) & $\begin{array}{l}\text { Revenue } \\
(\mathrm{US} \$) / \mathrm{m}_{3}\end{array}$ & $\begin{array}{l}\text { Input costs } \\
(\mathrm{US} \$) / \mathrm{m}^{3}\end{array}$ & $\begin{array}{l}\text { Profits } \\
(\mathrm{US} \$) / \mathrm{m}^{3}\end{array}$ \\
\hline Private Prices & 465.8 & 15.3 & 450.5 \\
\hline Social Prices & 511 & 20.9 & 490.1 \\
\hline Divergence effects & -45.2 & -5.6 & -39.6 \\
\hline
\end{tabular}

Source: Authors' computation based on FC and ISSER (2008) data.

\section{Analysis and Discussion of Results}

Five categories of research results in empirical PAM analysis emerge from the PAM matrix. These results flow directly from applying either the profitability identity or the divergence identity as shown in the previous section. These are private profits (US\$450.5), social profits (US\$490.1), output transfers (-US\$45.2), input transfers (-US\$5.6), and net transfers (-US\$39.6).

\section{Private and Social Profits}

Table 2 shows private profits of US $\$ 450.50$ per cubic meter of forest output. Profits in PAM are excess profits or the returns to management. That is, the residual after all costs of production have been accounted for including a normal return to capital (Pearson, Gotsch \& Bahri, 2003). When a commodity system earns positive private profits, the system is able to compete at current market prices, which include the effects of all policies and market failures. Competiveness is a result of interest to forestry sector producers (loggers, traders, and processors) and to policy makers 
concerned with forestry. But competiveness (positive private profitability) is also a concern of policy makers for promoting investments to accelerate economic growth, because new investment must increase (or at least not reduce) private profitability if forestry sector producers are to expand their production activities. The extent of private profitability indicates that investors will continue to be attracted to the forestry sector in Ghana to benefit from existing profits.

From Table 2, the social profitability is US\$490.10 per cubic meter of output. Efficiency is a measure of how the country might best allocate its scarce resources to provide the most output and incomes. When a commodity system earns positive social profits as is the case above, the system is able to compete at international prices without any assistance from government. Social profits are thus supposed to be of interest mainly to government officials concerned with promoting rapid economic growth. New investments have to be socially profitable if they are to maximise growth opportunities. Hence the positive social profits for Ghana are an indication that growth opportunities exist through the forestry sector.

The excessively high private and social profits (relative to the stumpage prices) within the forestry sector in Ghana revealed by the PAM analysis have largely been due to low stumpage prices and over exploitation of timber with accompanying externalities for the rest of the economy (Birikorang et al., 2007). This shows a seeming competitiveness exists which benefits mostly rich timber merchants and leads to strengthening the existing overcapacity in the sector.

Thus despite the seeming favourable PAM profitability values, the underlying factors, namely, low stumpage prices, over exploitation and high externalities, show that the figures are due to a distorted pricing system. Policies affecting pricing of Ghana's timber have consistently worked in favour of international profitability interests to the detriment of local interests, giving the false impression of profitability in the industry. This has happened through forestry policy sustaining the status quo of low stumpage prices, over exploitation of timber and externalities. This means that implemented forestry policy has disorganised the sector to the extent of providing unrealistic information on private and social profitability. Hence, in real terms, the implementation of forestry policy has been both privately and socially inefficient. This result is supported by the World Bank (2006) assertion that profitability in Ghana's forestry sector only serves to enrich the rich merchants to the disadvantage of the ordinary people in the industry. 


\section{Divergence}

The divergence effect of both revenue and costs are shown to be -45.2 and -5.6 US dollars per cubic meter respectively in Table 2. This means that forestry policy implementation has had adverse impacts on both revenues and costs within Ghana's forestry sector. Table 2 shows that the net divergence for forestry policy in Ghana is US\$ - 39.6o per cubic meter of forestry output. Private valuations of output and inputs differ from social valuations because something gets in the way to make the observed market valuation (the private price) diverge from the efficient valuation or social opportunity cost (the social price). The government might have decided to raise or lower the market price by introducing tax or subsidy policies, trade restrictions, or other policy interventions - collectively called distorting policies. Or the market might be imperfect and failed to provide efficient valuations because of market failures like monopolies, externalities, or underdeveloped factor markets. Hence, if the observed market price differs from the desired efficient level, the divergence must be caused either by a distorting policy or by a market failure.

Efficient policy is government intervention to correct market failure and thus offset a divergence. For example, if monopoly is efficiently regulated through forestry policy, seller prices would cause private and social costs to become equal, which will result in an increase in incomes for forestry sector stakeholders. From the PAM analysis, both the divergence in revenue and costs were negative. This shows that forestry policy increasingly distorts the sector's revenue and costs. The net divergence being negative simply goes to reaffirm the distorting effects of forestry policy in Ghana. Thus, since the implementation of forestry policy in Ghana exerts a distorting influence on the sector, it cannot be efficient. 


\section{Summary Ratios}

Another set of indicators for policy evaluation obtained from the PAM framework are summary ratios as discussed earlier. These are presented in Table 3.

Table 3: Summary ratios for forestry sector PAM in Ghana

\begin{tabular}{|l|l|l|l|}
\hline Ratio & Formula from PAM table & Value & Implication for forestry policy \\
\hline EPC & $\frac{R P-C P}{R S-C S}$ & 0.92 & $\begin{array}{l}\text { Forestry policy reduces local profits relative } \\
\text { to social profits by } 8 \% .\end{array}$ \\
\hline NPC & $\frac{C P}{C S}$ & 0.73 & $\begin{array}{l}\text { Forestry policy reduces local revenues or } \\
\text { market prices relative to World prices by } \\
27 \% .\end{array}$ \\
\hline SRP & $\frac{D P}{D s}$ & -0.08 & $\begin{array}{l}\text { Forestry policy causes local revenues to } \\
\text { decrease relative to social revenues due to } \\
\text { transfers by 8\%. }\end{array}$ \\
\hline
\end{tabular}

Source: Authors' computations based on Table 2.

The Nominal Protection Coefficient (NPC) is a ratio that contrasts the observed (private) forestry price with a comparable world (social) price. This ratio shows the impact of forestry policy that causes a divergence between the two prices (Monke \& Pearson, 1989). If NPC is less than one, it implies that forestry policy is reducing private revenue or market prices, and making them lower than the world price for forest resources. For the case of Forestry Policy in Ghana, the NPC of 0.73 means that Forestry Policy in Ghana reduces the private revenue or market prices by $27 \%$ per cubic meter. This means that domestic operators in the forestry sector are not protected by forestry policy and are making losses or being taxed through forestry policy, thus reducing their welfare and capacity for inclusive growth.

The Effective Protection Coefficient (EPC) is the ratio of value added in private prices to value added in world prices. The coefficient measures the degree of policy transfer from product market policies. An EPC $<1$ implies the system has lost almost all the protection, mainly in the form of subsidies that existed on inputs before policy reforms. Thus through forestry policy in Ghana, subsidies are lost to the world and hence welfare is reduced for residents.

The third computed incentive indicator from the PAM is the Subsidy Ratio to Producers (SRP). This is the net policy transfer as a proportion of total social revenue. It shows the proportion of revenue in world prices that would be required if a single subsidy or tax were substituted for the entire set of commodity and macroeconomic policies (Monke \& Pearson, 1989). The SRP permits comparisons of the extent to which all policy subsidises the forestry system. From Table 3, the 
negative SRP means that forestry policy taxes the forestry sector, thus reducing the welfare of workers in the sector.

\section{Sensitivity Analysis}

Sensitivity analysis was intended to find out the levels of factors and investments that could result in more efficient allocation of forestry resources due to forestry policy. The use of sensitivity analysis thus provides an analytical technique which tests systematically what happens to the earning capacity of Ghana's forestry sector if events differ from the estimates made about them in planning (Gittinger, 1982). The sensitivity analysis also addresses uncertainty about future events. The analysis is done by varying one element and determining the effect of that change on the outcome of policy.

For forestry policy in Ghana, the sensitivity is captured by elasticity of forestry policy divergences with respect to factor parameters - cost of inputs. The effect of $5 \%$ and $10 \%$ rises and falls respectively of costs of inputs were obtained to ascertain the influence of small changes on the transfer of benefits due to forestry policy in Ghana. Table 4 shows the results of the sensitivity analysis.

Table 4: Sensitivity analysis of net divergence to changes in input prices

\begin{tabular}{|l|l|l|l|l|}
\hline Parameter & \multicolumn{4}{|c|}{ Change in value } \\
\hline Percentage change in input price & $5 \%$ increase & $10 \%$ increase & $5 \%$ decrease & $10 \%$ decrease \\
\hline Elasticity of net divergence & 0.02 & 0.04 & 0.02 & 0.04 \\
\hline
\end{tabular}

Source: Authors' computation based on Table 3.

The sensitivity analysis from Table 4 shows that a 5\% change in the price of inputs due to forestry policy, will produce a corresponding change in net divergence of 0.02 , which is $2 \%$. This implies inelasticity, indicating that divergence is generally not responsive to changes in input prices in Ghana. This is reinforced by the effect of the $10 \%$ change in input prices, which produces only a $4 \%$ change in net divergence. The derived net divergence elasticity suggests a relatively high degree of stability in input costs. Thus in each case of the change, there was a worsening of net divergence.

The inelasticity of changes in net divergence relative to changes in input prices indicates a worsening of net divergence with changing input prices within the Ghanaian forestry sector. Worsening divergence implies more distortions and greater externalities, which will result in lower welfare for the Ghanaian economy. 
Thus, the sensitivity analysis confirms the fact that implemented forestry policy has not been efficient in Ghana.

\section{Conclusion and Policy Implications}

The study evaluated the efficiency of forestry policy implemented in Ghana, which has about 70 per cent of its population depending on forest resources for livelihood and cultural purposes. It employed an inclusive wealth theoretical framework to ascertain the social opportunity cost due to forestry policy implementation in Ghana, an indicator of the economic welfare effect of the policy. Data from Ghana Forestry Commission was analysed using the Policy Analysis Matrix. The results show that the 1994 forestry policy implementation in Ghana has resulted in distortions in private and social profitability to the detriment of local communities. It has contributed to the distorting influence on revenues and costs, taxing the forestry sector and subsidising external consumption of timber as against local consumption. Forestry policy has also worsened distortions and externalities in the forestry sector. Hence, based on profitability, divergence, summary ratios and sensitivity analyses, this evaluation concludes that the implementation of forestry policy in Ghana has not been efficient and failed to promote inclusive growth. Future research should seek to investigate the extent to which each forestry policy instrument has contributed to inefficiency in Ghana's forestry sector and the monetary value lost through each contribution.

Major policy reforms are recommended for Ghana's forestry sector to secure the total economic value of forests for sustained inclusive growth and development. Such moves would require an application of the holistic model, where the ecological, social and economic subsectors of the forestry sector are accorded equal recognition in the entire forestry policy process. The 2012 forestry and wildlife policy still has the gaps discussed above. The most important additions to the 1994 policy by the 2012 policy were climate change related issues.

To reverse the inefficiency, the formulation and implementation of forestry policy needs to consciously pursue efficiency as a goal. The goal of the current policy excludes economic efficiency; a mention however was made of attaining technical efficiency in the tertiary wood sector, which is too far from the standard for policy implementation efficiency. The economic subsector of Ghana's forestry sector has received some amount of recognition. However, it has been relegated to the background and is only provided an opportunity to contribute in policy decisions when issues about money arise. It is also worth noting that most of the times, natural scientists have assumed the role of forestry economists and carried out 
superficial assessments to inform policy, instead of involving natural resource economists. In effect, the required involvement of economists for the holistic approach has mostly been non-existent.

The issue of efficiency of forestry policy belongs more to the economic subsector than to the ecological subsector. The inability to correctly plan for efficient performance and evaluation of forestry policy by the authorities also demonstrates the lack of a full scale inclusion of the economic and social subsectors in forestry policy issues. To attain inclusive economic growth, both economists and foresters must play equally important roles from the beginning to the end of the various activities involved in the forestry policy process. Without this, it will be unlikely to attain real inclusive economic growth through the forestry sector. Thus, the way forward in this regard is to engage forestry, ecological and natural resource economists, tasked to participate in all stages of the forestry policy process on an equal level of importance as foresters. This will help secure the total economic value of Ghana's forests, through efficient policy implementation for sustained inclusive growth and development.

\section{Acknowledgements}

The authors are grateful to the Global Green Growth Knowledge Platform for sponsoring the corresponding author to present an earlier version of this paper at the Fourth Annual Conference on Transforming Development through Inclusive Green Growth, 6-7 September 2016, Jeju International Convention Center, Republic of Korea, and also for a review of the paper for the Conference.

\section{References}

Alemagi, D., Samjee, A. and Davis, A. (2007). Comparison of economic growth and governance between high forest and low forest countries. In Seeing People through the Trees: Scaling up Efforts to Advance Rights and Address Poverty, Conflict, and Climate Change, Washington DC: Rights and Resource Initiative.

Arrow, K.J., Dasgupta, P. and Maler, K.G. (2003). Evaluating projects and assessing sustainable development in imperfect economies. Environmental and Resource Economics, 26(4), pp. 647-685.

Baah-Nuakoh, A. (2003). Environmental, Informal Sector and Factor Markets.Accra: Woeli Publishing Services, pp. 22-26.

Birikorang, G., Hansen, C.P. and Treue, T. (2007). Fiscal study report. Validation of Legal Timber Programme. Accra, Ghana: Forestry Commission of Ghana. 
Boon, E., Ahenkan, A. and Baduon, B.N. (2009). An Assessment of Forest Resources Policy and Management in Ghana. In 'IAIAog Conference Proceedings', Impact Assessment and Human Well-Being, 29th Annual Conference of the International Association for Impact Assessment, 16-22 May 2009, Accra International Conference Center, Accra, Ghana.

Collins, R., Sakhrani, V., Selin, N., Alsaati, A. and Strzepek, K. (2014). Using inclusive wealth for policy evaluation: the case of infrastructure capital. In UNUIHDP and UNEP. Inclusive Wealth Report 2014. Measuring progress toward sustainability. Cambridge: Cambridge University Press, pp. 179-200.

Dasgupta, P. (2008). Discounting climate change. Journal of Risk and Uncertainty, $37(2 / 3)$ pp. 141-169.

Dasgupta, P. (2009). The welfare economic theory of green national accounts. Environmental and Resource Economics, 42(1), pp. 3-38.

Dasgupta, P. and Maler, K.G. (2000). Net national product, wealth, and social wellbeing. Environmental Development Economics, 5(1), pp. 69-93.

Food and Agricultural Organization (FAO) (2015). Global Forest Resources Assessment 2015. Rome: Food and Agriculture Organisation of the United Nations.

Ghana Forestry Commission (2012). Ghana Forestry and Wildlife Policy. Accra: Ministry of Lands and Natural Resources.

Ghana Forestry Commission (1994). Ghana Forestry and Wildlife Policy. Accra: Ministry of Lands and Natural Resources.

Gittinger, J.P. (1982). Economic Analysis of Agricultural Projects, $\left(2^{\text {nd }}\right.$ ed.) Baltimore MD: Johns Hopkins University Press, pp. 25-60.

Gundimeda, H. and Atkinson, G. (2014). Forest wealth of nations. In UNU-IHDP and UNEP. Inclusive Wealth Report (2014). Measuring progress toward sustainability. Cambridge: Cambridge University Press, pp. 137-158.

Institute of Economic Affairs (IEA) (2011). Trade for Sustainable Development: the story of Cocoa, Gold, and Timber. Accra, Ghana: Institute of Economic Affairs.

Institute of Statistical, Social and Economic Research (ISSER) (2011). The state of the Ghanaian Economy in 2010. University of Ghana, Legon, Ghana.

Institute of Statistical, Social and Economic Research (ISSER), (2008). The state of the Ghanaian Economy in 2007. University of Ghana, Legon, Ghana.

Keenan, R. (2015). Interview with ClickGreen staff. Retrieved from: www.university herald.com on $24^{\text {th }}$ September, 2015. 
Kotey, E., Francois, J.O., Yeboah, J., Amanor, K.S. and Antwi, L. (1998). Falling into place. Policy that works for forest and people, series. No. 4. London: International Institute for Environmental and Development, pp. 66-114.

Monke, E.A. and Pearson, S.R. (1989). The policy analysis matrix for agricultural development (No. E10 P362). Ithaca: Cornell University Press, pp. 24-111.

Nelson, G.C. and Panggabean, M. (1991). The Cost of Indonesian Sugar Policy. A Policy Analysis Matrix Approach. American Journal of Agricultural Economics 73(3): pp. 703-712.

Pearson, S., Gotsch, C. and Bahri, S. (2003). Applications of the Policy Analysis Matrix in Indonesian Agriculture, pp. 25-47.

Romer, P.H. (1989). Human capital and growth: theory and evidence. National Bureau of Economic Research. Retrieved from http://www.nber.org/papers/w3173 on $20^{\text {th }}$ March, 2016.

Seini, W.A. (2002). Agriculture growth and competitiveness under policy reforms in Ghana. Technical Publication NO. 16. Accra, Ghana: Institute of Statistical, Social \& Economic Research, University of Ghana, pp. 66-75.

World Bank (2006). Ghana country environmental analysis. Report Number 36985-GH. Washington D.C.: The World Bank. 